\title{
Forecasting the Inflation using Hybrid SARIMA- Single Exponential Smoothing for Determining Minimum Costs of Living Index in Bandung City
}

\author{
Irfan Dwiguna Sumitra ${ }^{1}$, Rifqi Fahrudin ${ }^{2}$, Sri Supatmi ${ }^{3}$ \\ \{irfan.dwiguna@email.unikom.ac.id ${ }^{1}$, rifqifhrdn@mahasiswa.unikom.ac.id $^{2}$, \\ sri.supatmi@email.unikom.ac.id ${ }^{3}$ \} \\ Postgraduate Department of Information System, Universitas Komputer Indonesia ${ }^{1}$, \\ Department of Information Management, Universitas Komputer Indonesia ${ }^{2}$, \\ Department of Computer Engineering, Universitas Komputer Indonesia ${ }^{3}$
}

\begin{abstract}
This research aims to produce inflation data forecast and then to forecast the results to an estimation of the Costs of Living Index (KHL). However, this research is limited and merely discuss the KHL by categories of food and beverages entirely. Although inflation could be predicted with high accuracy, surely it could rely upon for making the Government in anticipating future economic activity. Based on previous research, the SARIMA method and Single Exponential Smoothing could show the results of forecasting that is adequate to follow; the value of inflation can be measured by the movements of the actual data. However, this study tried to combine these two methods where the results of the combined method produce more accurate forecasting compared to the results that only used a single method. Based on the results of merging SARIMA with a model $(1,0,1)$ $(1,0,1) 12$ and Single Exponential Smoothing with an alpha value of 0.6 overall, produces the smallest error value with MAD 114, MSE 0,017 and 0,39\% for MAPE. This indicates that the results of the forecasting method of SARIMA method and Single Exponential Smoothing value against inflation are very superfine and accurate. After that, the results of the inflation forecasting needs to be calculated with the value of KHL to become a reference for forecasting the value of KHL for a similar period with inflation forecasting results.
\end{abstract}

Keywords: Inflation, Forecasting, SARIMA, SES, KHL 


\section{Introduction}

Inflation is a tendency or movement of raising the levels of general prices that take place continuously from one period to the next. Inflation needs serious attention from the monetary authorities responsible for controlling inflation. If inflation can be predicted with high accuracy, it can be used as a basis for government policy-making in anticipating future economic activities. The indicator that is often used to measure inflation is the Consumer Price Index (CPI). Law No. 13 of 2003 concerning labor states that every worker/laborer has the right to obtain income that meets a decent livelihood for humanity [1].

According to the regulation of the Minister of Manpower and Transmigration RI No. 17 year 2005 about Components and Implementation of Stages in Achieving Decent Life Requirements stated that the requirements a standard that must be met by a single worker to be able to live physically, non-physically and socially for one-month requirements [2]. The component of needs for decent living act as a basis for determining minimum wage itself created an increase in the minimum life requirement based on presidential regulation No. 78 of 2015 on remuneration [3].

The minimum cost of living index, after this abbreviated as KHL, is the standard requirement of a single worker/laborer to be able to live physically fit in one month. Based on PP No.78 of 2015, adjustments to the KHL value are directly corrected through calculations with the national inflation rate for the current year. The number of types of needs initially has 46 types in the Minister of Manpower Decree RI No.17 of 2005 and becomes 60 types of KHL in the Minister of Manpower Decree No.13 of 2012 [4]. Forecasting is a method for estimating value in the future by using past data. Inflation data is one of the time-series data created by modeling past time data and can be used to forecast future time data. In forecasting the inflation rate where the data is in the form of time series, the Seasonal Autoregressive Integrated Moving Average method, better known as the SARIMA method can show the forecasting results that can follow the movement of the actual data from the inflation rate.

This study will use and combine the SARIMA and SES methods by looking at seasonal patterns as an attempt to produce forecasting that is more accurate and closer to the actual value. It is necessary to calculate KHL for a single worker in fulfilling the needs of a decent life both physically and non-physically. From the results of forecasting, the inflation value will be calculated to determine the KHL value for the next period under the results of inflation forecasting values.

\section{Material and Methods}

\section{A. Inflation}

Inflation is a condition that results in general price increases or the process of increasing prices in general and continuously [5]. Inflation, in other words, is the process of decreasing the value of currency continuously. Inflation is a process of an event and not a high or low price level. So, do not assume that a high price level means high inflation. Inflation occurs when the process of continuous price increases and influences affect each other. The indicator that is often used to measure the inflation rate is the Consumer Price Index (CPI) [6]. The consumer price index is a measurement of the average price change of a commodity package in a given period. 


\section{B. Decent Living Costs (KHL)}

Based on the Regulation of the Minister of Manpower and Transmigration of the Republic of Indonesia No. 17 of 2005 about Components and Implementation of Stages of Achieving Decent Life Needs, stated that Decent Living Needs is a standard of needs that must be fulfilled by a single worker to live physically, non-physically and socially needs of one month. The number of types of needs initially 46 types in the Minister of Manpower Decree No. 17 of 2005 became 60 types of KHL in the Decree of the Minister of Manpower No. 13 of 2012. In addition to the addition of 14 new types of KHL, there were also adjustments/additions to the type of quality and quantity of KHL and changes in types of needs. The following table is the components of the food and beverage component of the standard decent living needs based on Minister of Manpower Decree No. 13 of 2012:

Table 1. Standard Decent Living Costs

\begin{tabular}{|c|c|c|c|}
\hline No & Components & $\begin{array}{l}\text { Quality/ } \\
\text { Criteria }\end{array}$ & Needs \\
\hline \multicolumn{4}{|c|}{ I. Food and Drink } \\
\hline 1 & Medium Rice & Medium & $10 \mathrm{~kg}$ \\
\hline \multirow[t]{4}{*}{2} & Protein Source: & & \\
\hline & a. Meat & Medium & $0.75 \mathrm{~kg}$ \\
\hline & b. Fresh fish & Good & $1.2 \mathrm{~kg}$ \\
\hline & c. Chicken eggs & Good & $1 \mathrm{~kg}$ \\
\hline 3 & Nuts: tempeh / tofu & Good & $4.5 \mathrm{~kg}$ \\
\hline 4 & Milk powder & Medium & $0.9 \mathrm{~kg}$ \\
\hline 5 & Sugar & Medium & $3 \mathrm{~kg}$ \\
\hline 6 & Cooking oil & Bulk & $2 \mathrm{~kg}$ \\
\hline 7 & Vegetables & Good & $7.2 \mathrm{~kg}$ \\
\hline 8 & $\begin{array}{l}\text { Fruits (equivalent to } \\
\text { banana / papaya) }\end{array}$ & Good & $7.5 \mathrm{~kg}$ \\
\hline 9 & $\begin{array}{l}\text { Other carbohydrates } \\
\text { (equivalent to flour) }\end{array}$ & Medium & $3 \mathrm{~kg}$ \\
\hline 10 & Tea or Coffee & $\begin{array}{l}\text { Dip / } \\
\text { Sachet }\end{array}$ & 2 Box 25 \\
\hline 11 & Spices & $\begin{array}{l}\text { Value } 1 \text { to } \\
10\end{array}$ & $15 \%$ \\
\hline
\end{tabular}

More information about the components of Decent Life Needs (KHL) can be seen in Decree of the Minister of Agriculture No. 13 of 2012.

\section{Forecasting}

Forecasting is an activity to estimate what will happen in the future [7]. Forecasting is a vital part of every business organization and for every management decision making. Time series forecast is a series of observations of a variable taken from time to time and recorded sequentially in the order of time [8].

\section{SARIMA}

Seasonal Autoregressive Integrated Moving Average or also known as SARIMA is a time series forecasting method for stochastic data models with seasonal data patterns.

In general, SARIMA notations are [9]:

SARIMA (p,d,q)(P,D,Q) $)^{\mathrm{s}}$ 
with:

$\mathrm{p}, \mathrm{d}, \mathrm{q}$ : Parts are not seasonal from the model

$(\mathrm{P}, \mathrm{D}, \mathrm{Q}) \quad$ : Seasonal section of the model

$\mathrm{s} \quad$ : Number of periods per season

The general formula of SARIMA (p, d, q) (P, D, Q) $s$ is as follows:

$\Phi p B^{S} \phi_{p}(B)(1-B)^{d}\left(1-B^{S}\right)^{D} Z_{t}=\theta_{q}(B) \Theta_{q}\left(B^{S}\right) a_{t}$

with:

$p B$ : AR Non-Seasonal

$\Phi p B^{S} \quad$ : AR Seasonal

$(1-B)^{d} \quad:$ differencing non seasonal

$\left(1-B^{S}\right)^{D} \quad$ : differencing seasonal

$\theta q(B) \quad$ : MA non seasonal

$\Theta q\left(B^{S}\right) \quad$ : MA seasonal

In setting the $\mathrm{p}$ and $\mathrm{q}$ values can be helped by observing the Autocorrelation Function (ACF) and Partial Autocorrelation Function (PACF) patterns concerning the following table [10]:

Table 2. ACF And PACF Patterns for Tentative Parameter Identification

\begin{tabular}{lll}
\hline Model & Pola ACF & Pola PACF \\
\hline AR (p) & Declining rapidly (dies down) & $\begin{array}{l}\text { Significant spike appears until } \\
\text { the lag is p and the cut off after } \\
\text { the p-lag } \\
\text { declining rapidly (dies down) }\end{array}$ \\
MA (q) & $\begin{array}{l}\text { Significant spike appeared until } \\
\text { the q lag and cut off after the q- }\end{array}$ & $\begin{array}{l}\text { lag } \\
\text { ARMA (p,q) }\end{array}$ \\
Declining rapidly (dies down) & Declining rapidly (dies down)
\end{tabular}

AR (p) or MA (q) Significant spike appeared until the $q$ lag and cut off after the qlag

AR (p) Declining rapidly (dies down)

Significant spike appeared until the p-lag and cut off after the plag Significant spike appears until the lag is $\mathrm{p}$ and the cut off after the p-lag

The residual examination stages are divided into Ljung Box (white noise) and residual normality checks. Testing to fulfill the white noise assumption was carried out by L-Jung Box testing with a hypothesis:

$\mathrm{H}_{0}: \rho_{1}=\rho_{2}=\rho_{\text {... }}=\rho_{k}=0$

$\mathrm{H}_{1}$ : there is at least one value $\rho_{k} \neq 0$, with $\mathrm{k}=1,2, \ldots, \mathrm{K}$ with test statistics:

$$
Q=n(n+2) \sum_{k=1}^{K} \quad(n-k)^{-1} \hat{\rho}_{k}
$$

Where $\mathrm{n}$ is many observations and $\hat{\rho}_{k} \mathrm{~s}$ the residual $\mathrm{ACF}$ sample in the $\mathrm{k}$ lag, and $\mathrm{K}$ is the maximum lag. Critical area $=\mathrm{Q}>x_{(a, K-m)}^{2}$ or $P$-value $<\alpha=5 \%$.

The Kolmogorov-Smirnov test can do testing for normal distribution with a hypothesis:

$\mathrm{H}_{0}$ : residuals are normally distributed

$\mathrm{H}_{1}$ : residuals are not normally distributed With statistics test:

$$
D={ }_{x}^{\operatorname{Sup}}\left[\left|F_{n}(x)-F_{0}(x)\right|\right]
$$


Where $\mathrm{D}$ is the maximum absolute deviation value between $\mathrm{F}(\mathrm{x}) \mathrm{n}$ and () $0 \mathrm{~F} \mathrm{x}$, Each soup is a Kolmogorov cumulative opportunity function calculated from the sample data, the cumulative probability function of the normal distribution and the supremum value for all $\alpha_{\mathrm{t}}$. Critical Area: ignore $\mathrm{H} 0$ if $D \geq D_{(1-\alpha, n)}$ or $P$-value $<\alpha$, with $\alpha=5 \%$. The best model is determined based on the error value, the smaller the error value produced, the better the model and at the same time determines the model that is suitable for use in forecasting. The following figure is the forecasting process using the SARIMA method.

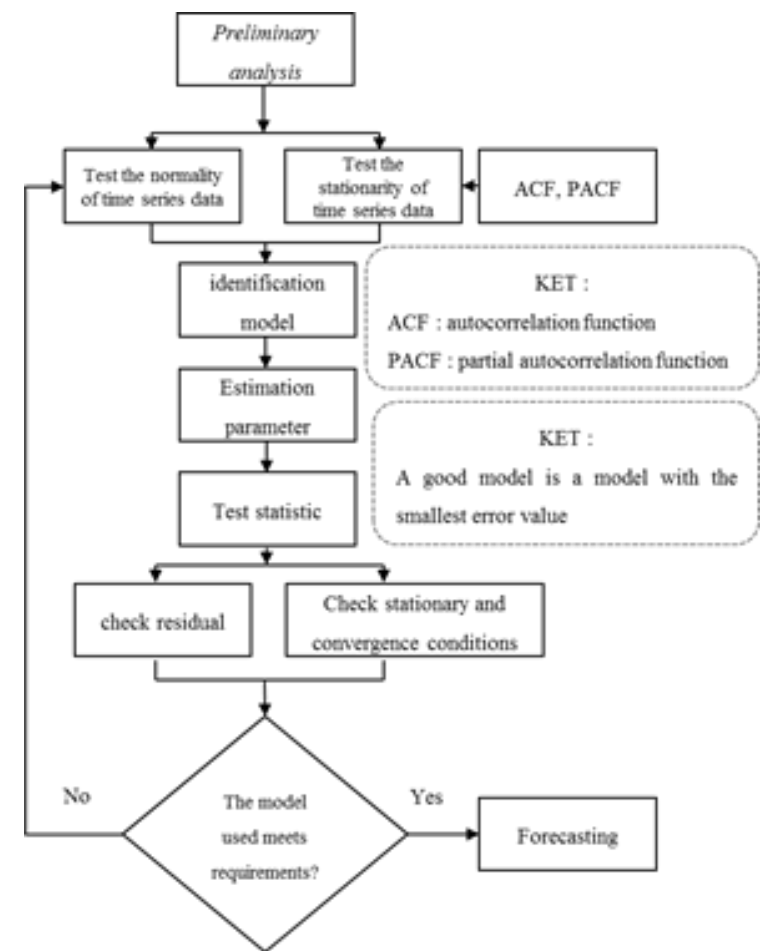

Fig. 1. The phase of the SARIMA Method

In figure 1, the forecasting process is shown using the SARIMA method. In the initial stage, an initial analysis of the data pattern is carried out after the normality and stationarity of historical data are tested. At this stage, the test results are indicated by ACF and PACF. After that, a statistical test is performed with estimated parameters. Testing these statistics results in residual independence. From this residual, independence and normality will be examined, so that it will be known whether the SARIMA model is used well or not. The best SARIMA model is the model with the smallest error value. The error value in this study was obtained by calculating the values of MAD, MSE, and MAPE.

\section{E. Single Exponential Smoothing}

This method is also called a single exponential smoothing that is commonly used by traders for short-term forecasting. The model assumes if data fluctuates around a fixed mean value and also without a trend or consistent growth pattern [11]. Unlike the Moving Average, Exponential Smoothing will offer greater emphasis at a time through the use of a smoothing constant. The basic formula is: 


$$
S_{t+1}=\left(a * X_{t}\right)+(1-\alpha) S_{t-1}
$$

with:

a: $\quad$ Smoothing constant

$\mathrm{t}$ : Time period

There is an alternative formula. For example, Roberts (1959) replaces yt-1 with current observations, y t. Other formulas use forecasts for the previous period and the current period:

$$
F t=F_{t-1}+a\left(A_{t-1}-F_{t-1}\right)
$$

with:

Ft-1 : Estimates for the previous period,

At-1 : Request the actual value for that period,

a : Weight (must be between 0 and 1). The closer to zero, the smaller the weight.

The following are the stages of using the Single Exponential Smoothing method.

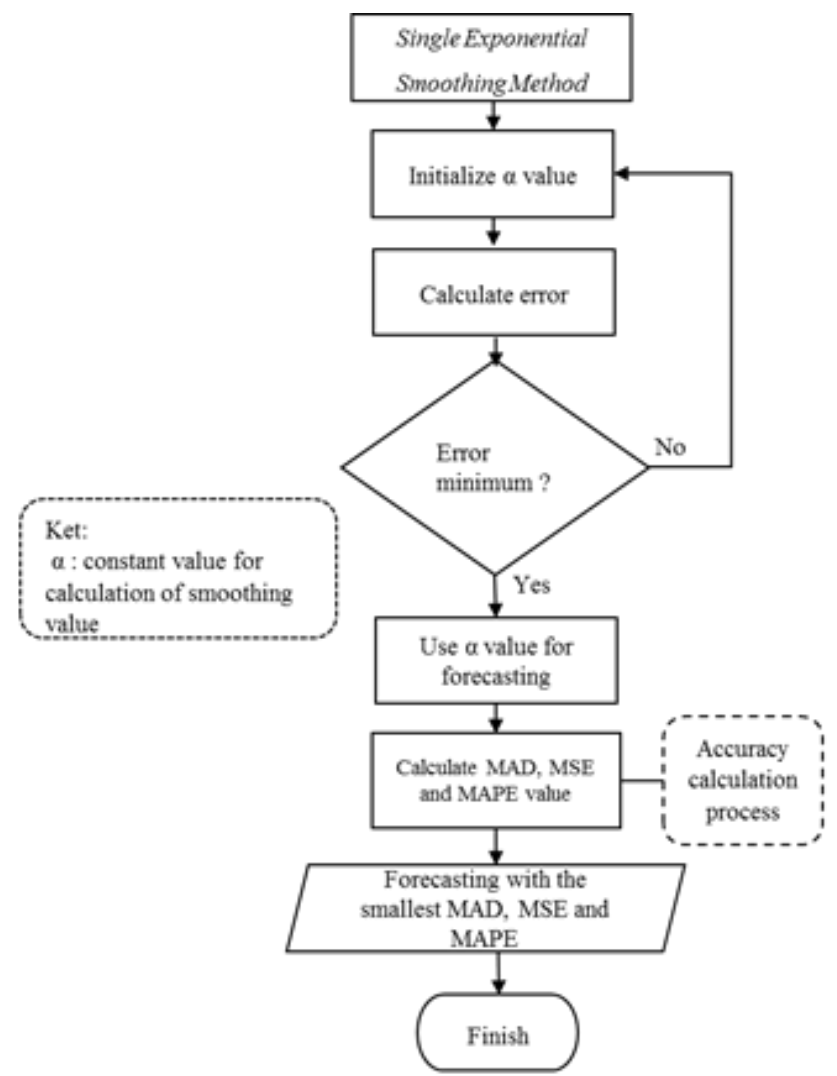

Fig. 2. The phase of Single Exponential Smoothing Method

Figure 2 is a description of the steps taken in the use of the Single Exponential Smoothing method. The forecasting steps with the SES method are analyzing the data, whether stationary by looking at the pattern formed, then the data is predicted using SES, then comparing the smallest error value. 


\section{F. Hybrid Method}

Three things are the reasons for using combination forecasting models [12]. First, it is often difficult to apply the use of linear models or non-linear models to a time series problem, so this combination model becomes a more accessible alternative. Second, rare time series are linear or nonlinear and often contain both in reality, where not only the ARIMA model and Neural Network can provide each model of cases, so this combination can be used to model the time series containing linear and non-linear. Third, some forecasting literature states that there is no single model that is best in each situation. An easy way to improve the accuracy of predictions is to combine several different methods in the same time series and to average the predictions produced, combining forecasting methods often results in better forecast accuracy. The following are the hybrid stages of the SARIMA method and Single Exponential Smoothing.

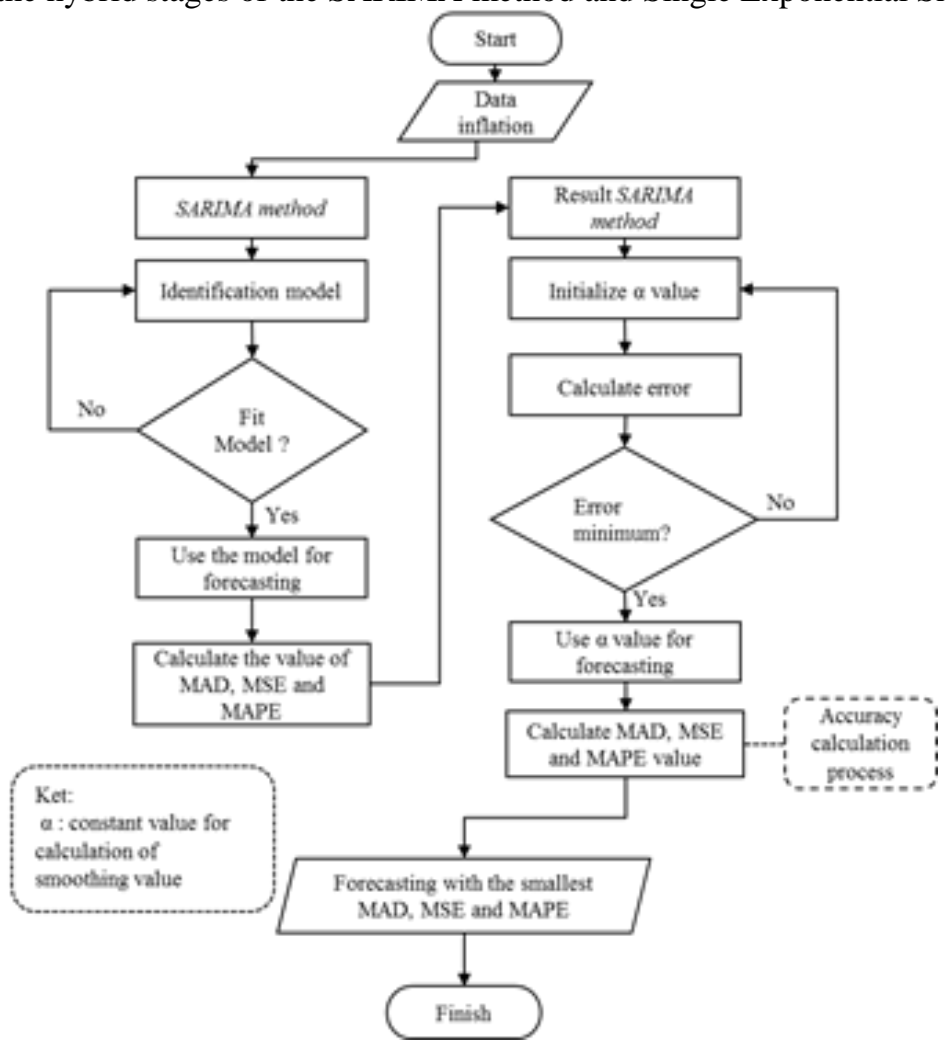

Fig. 3. Hybrid Method SARIMA and Single Exponential Smoothing

Figure 3 is an illustration of the combination of the SARIMA and SES methods; the initial stages of Bandung City inflation data will be predicted using the SARIMA method by the steps described earlier. The SARIMA model with the smallest error value will then be used as the initial input value for the SES method, then the forecasting result with the smallest error value will be calculated with the KHL value. The result of the calculation is the KHL value of forecasting results based on the inflation value that has been predicted using the combined method of SARIMA and SES. 


\section{G. Evaluation of Forecasting Results}

Evaluation of forecasting results is used to determine the accuracy of the forecasting results that have been made on the actual data. There are many methods for calculating forecasting errors. Some of the methods used are:

Mean Absolute Deviation is a measure of the overall forecasting error for a model. The MAD value is calculated by taking the absolute number of forecast errors divided by the number of data periods (n) [13].

$$
M A D=\frac{\sum \quad \mid \text { actual data }- \text { forecasting } \mid}{n}
$$

with:

$\mathrm{n}=$ number of data periods

Mean Squared Error is the average difference in squares between predicted and observed values. The disadvantage of using MSE is that this evaluation method tends to accentuate an enormous deviation value due to the adherence to it.

with:

$$
M S E=\frac{\sum \quad(\text { erro forecasting })^{2}}{n}
$$

$\mathrm{n}=$ number of data periods

Mean Absolute Percentage Error is the average value of the absolute difference between the value of the forecasting result and the actual value, and the value is shown in percentage [14].

$$
\text { MAPE }=\sum_{t=1}^{T} \quad \frac{\mid \text { forecasting }- \text { actual } \mid}{\text { actual }} * 100
$$

\section{Result and Discussion}

\section{A. Forecasting Using SARIMA Method}

The data used in this forecasting is Bandung City inflation data based on CPI in 2011 2017. Data was taken from the Central Statistics Agency (BPS) Bandung City.

Table 3. Data Inflation January 2011 - December 2017

\begin{tabular}{lccccccc}
\hline Inflation & $\mathbf{2 0 1 1}$ & $\mathbf{2 0 1 2}$ & $\mathbf{2 0 1 3}$ & $\mathbf{2 0 1 4}$ & $\mathbf{2 0 1 5}$ & $\mathbf{2 0 1 6}$ & $\mathbf{2 0 1 7}$ \\
\hline January & 0,32 & 1,24 & 0,64 & 1,09 & $-0,05$ & 0,53 & 0,49 \\
February & $-0,05$ & $-0,05$ & 1,03 & 0,39 & $-0,37$ & $-0,15$ & 0,38 \\
March & $-0,01$ & 0,05 & 0,64 & 0,11 & 0,61 & 0,21 & $-0,02$ \\
April & $-0,02$ & 0,18 & $-0,21$ & 0,05 & 0,43 & $-0,17$ & 0,11 \\
May & 0,12 & $-0,23$ & 0,34 & 0,19 & 0,28 & 0,24 & 0,47 \\
June & 0,17 & 0,55 & 1,29 & 0,21 & 0,72 & 0,64 & 0,99 \\
July & 0,51 & 1,07 & 3,11 & 0,75 & 0,85 & 0,71 & $-0,27$ \\
Augustus & 0,38 & 0,64 & 1,39 & 0,41 & 0,49 & 0,49 & 0,06 \\
September & $-0,21$ & 0,06 & $-0,49$ & 0,57 & $-0,01$ & 0,14 & 0,11 \\
\hline
\end{tabular}




\begin{tabular}{lccccccc}
\hline Inflation & $\mathbf{2 0 1 1}$ & $\mathbf{2 0 1 2}$ & $\mathbf{2 0 1 3}$ & $\mathbf{2 0 1 4}$ & $\mathbf{2 0 1 5}$ & $\mathbf{2 0 1 6}$ & $\mathbf{2 0 1 7}$ \\
\hline October & 0,19 & 0,34 & $-0,06$ & 0,14 & $-0,06$ & 0,14 & $-0,03$ \\
November & 0,47 & $-0,11$ & $-0,24$ & 1,27 & 0,19 & 0,52 & 0,39 \\
December & 0,85 & 0,19 & 0,33 & 2,34 & 0,78 & 0,64 & 0,73 \\
\hline
\end{tabular}

Table 3 is a time series data of Bandung City inflation value as the initial data for forecasting in this study. The first step taken in the SARIMA method is the model identification process.

\section{1) Identification Model:}

The process of identifying the data model is done by looking at the original data plot, as well as seeing whether the data is stationary or not by looking at the ACF and PACF plots. Based on Bank Indonesia inflation increases when one month before Eid al-Fitr and then decreases or stabilizes when one month after Eid al-Fitr. This is because there is a sudden increase in foods, due to increased consumption and due to public expectations about price increases ahead of Eid Al-Fitr.

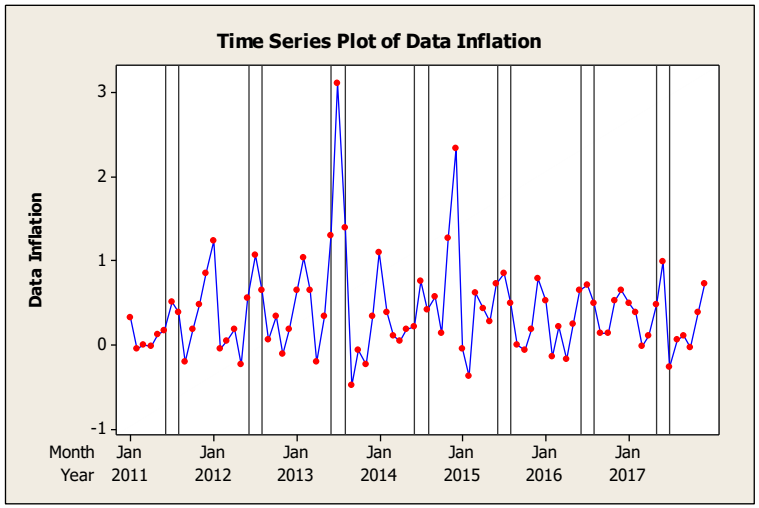

Fig. 4. Seasonal Pattern Data Inflation

Figure 4 shows that seasonal patterns influence the data due to the repetition of patterns in specific periods (yearly). 


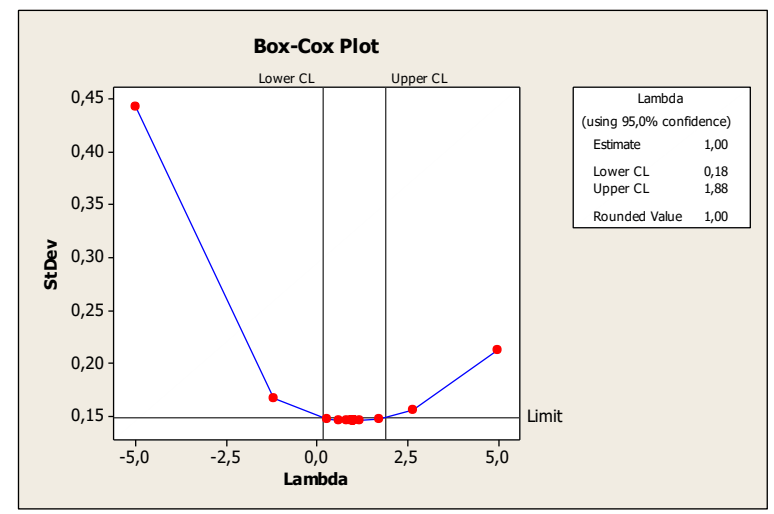

Fig. 5. Process Box-Cox Transformation

Figure 5 shows the results of the data transformation process with Box-Cox Transformation. The status data is stationary to the variety because the Rounded Value on the Box-Cox plot is already worth 1.00 .

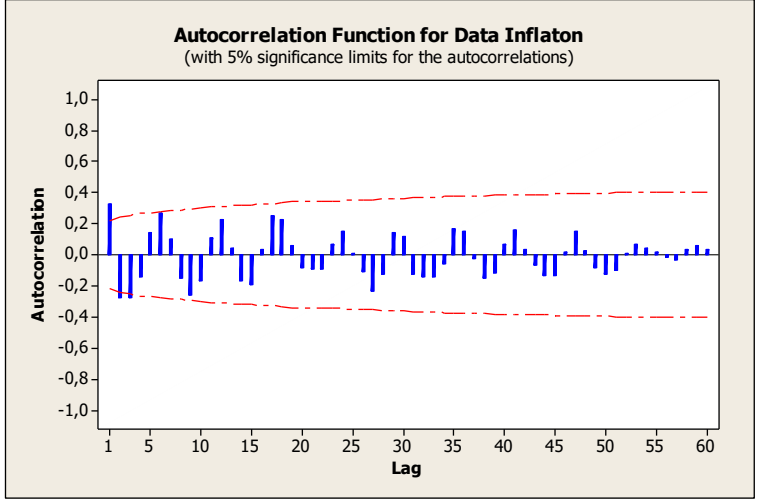

Fig. 6. Plot ACF

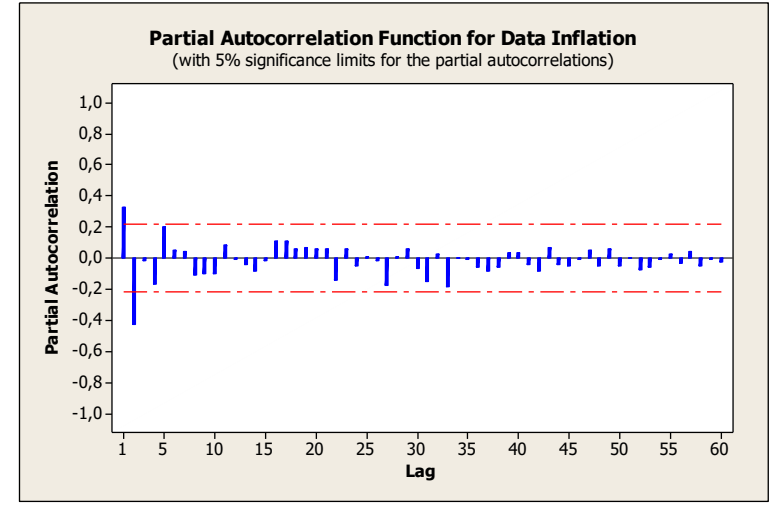

Fig. 7. Plot PACF

Figures 6 and 7 show the plot of ACF and PACF, where plots of ACF and PACF can be used to identify candidate models suitable for Bandung City inflation data. If ACF and PACF show 
die down, which means that both the ACF pattern and the PACF pattern have decreased dramatically at each lag, it can be said that the SARIMA model is a combination of AR and MA.

\section{2) Estimation Parameter:}

Candidate models are generated from previous estimates by looking at the ACF and PACF patterns, which state that the model is a combination of AR and MA. The following is the model produced by the SARIMA method on inflation movements in the city of Bandung.

Table 4. Candidate Model SARIMA Data Inflation

\begin{tabular}{ccccc}
\hline $\begin{array}{c}\text { Model SARIMA } \\
(\mathbf{p}, \mathbf{d}, \mathbf{q})(\mathbf{P}, \mathbf{D}, \mathbf{Q})^{\mathbf{1 2}}\end{array}$ & MAD & MSE & MAPE & Information \\
\hline $\begin{array}{c}\text { SARIMA } \\
(1,1,1)(1,1,0)^{12}\end{array}$ & 0,364 & 0,214 & $1,04 \%$ & Not Significant \\
$\begin{array}{c}\text { SARIMA } \\
(1,1,1)(1,1,1)^{12}\end{array}$ & 0,369 & 0,155 & $1,03 \%$ & $\begin{array}{c}\text { Not } \\
\text { SARIMificant }\end{array}$ \\
$\begin{array}{c}\text { SARIMA } \\
(1,1,0)(1,1,0)^{12}\end{array}$ & 0,308 & 0,152 & $0,81 \%$ & Not Significant \\
$\begin{array}{c}\text { SARIMA } \\
(1,0,1)(1,1,1)^{12}\end{array}$ & 0,142 & 0,025 & $0,45 \%$ & Significant \\
$\begin{array}{c}\text { SARIMA } \\
(1,0,1)(1,0,1)^{12}\end{array}$ & 0,141 & 0,025 & $0,42 \%$ & Significant \\
\hline
\end{tabular}

From Table 4 above it can be concluded that the SARIMA model $(\mathrm{p}, \mathrm{d}, \mathrm{q})(\mathrm{P}, \mathrm{D}, \mathrm{Q})^{12}$ which meets the significance requirements is the SARIMA model $(1,0,1)(0,0,1)^{12}$ and SARIMA model $(1,0,1)(1,1,1)^{12}$ because all parameters are significant $(\mathrm{P}$-value $<0,05)$. While the best model for inflation data is SARIMA $(1,0,1)(1,0,1)^{12}$ because it has the smallest error value of 0.141 for MAD, 0.025 for MSE and $0.42 \%$ for MAPE. It shows that this model is good for forecasting.

3) Check Residual:

After the SARIMA model $(\mathrm{p}, \mathrm{d}, \mathrm{q})(\mathrm{P}, \mathrm{D}, \mathrm{Q})^{12}$ obtained then a residual examination was carried out, namely white noise test and residual normality on the model used. The white noise test in the SARIMA method is seen from the L-Jung Box value (the value of $\mathrm{Pr} / \mathrm{P}$-value in the Minitab software). The value of P-value for each lag is higher than 0.05 , so it can be concluded that the residuals produced by the SARIMA model have white noise.

\begin{tabular}{llllll}
\multicolumn{3}{l}{ Modified } & \multicolumn{2}{l}{ Box-Pierce } & \multicolumn{2}{l}{ (Ljung-Box) } \\
\multicolumn{3}{l}{ Chi-Square statistic } \\
Lag & 12 & 24 & 36 & 48 \\
Chi- & 18,7 & 29,7 & 45,4 & 52,3 \\
Square & 18 & 21 & 33 & 45 \\
DF & 9 & 21 & \\
P- & 0,02 & 0,09 & 0,07 & 0,21 \\
Value & 8 & 9 & 3 & 1
\end{tabular}

To see whether the residuals are normally distributed, it can be done by testing KolmogorovSmirnov by comparing the distribution of data to be tested for normality with a standard normal distribution. 


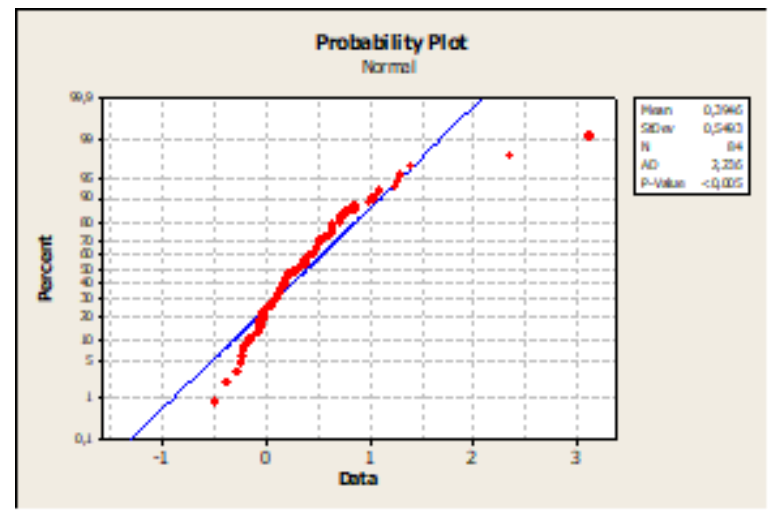

Fig. 8. Plot Normal Residual

In figure 8, the data can be seen around a straight line even though some points deviate far enough from a straight line. Thus, it can be interpreted that the residuals are identical and normally distributed.

4) Forecasting Result SARIMA Method:

The following are the forecasting results produced by the SARIMA method on inflation movements in 2011 - 2017 in the city of Bandung.

Table 5. Forecasting Value SARIMA Method

\begin{tabular}{llllll}
\hline $\begin{array}{l}\text { Period } \\
\mathbf{2 0 1 8}\end{array}$ & $\begin{array}{l}\text { Actual } \\
\text { Value } \\
\text { (a) }\end{array}$ & $\begin{array}{l}\text { Forecasting } \\
\text { Result } \\
(\mathrm{t})\end{array}$ & $\begin{array}{l}\text { Error } \\
\text { Absolut } \\
\left|\mathrm{A}_{\mathrm{t}}-\mathrm{F}_{\mathrm{t}}\right|\end{array}$ & $\begin{array}{l}\text { Square } \\
\text { Of Error } \\
\left|(\mathrm{At}-\mathrm{Ft})^{2}\right|\end{array}$ & $\begin{array}{l}\text { Absolute } \\
\text { Values } \\
\text { Of Errors } \\
|(\mathrm{At}-\mathrm{Ft}) / \mathrm{At}|\end{array}$ \\
\hline Jan & 0,83 & 0.68 & 0.15 & 0.021 & 0.18 \\
Feb & 0,22 & 0.30 & -0.08 & 0.006 & 0.35 \\
Mar & 0,21 & 0.17 & 0.04 & 0.002 & 0.21 \\
Apr & 0,27 & 0.09 & 0.18 & 0.033 & 0.67 \\
Mei & 0,22 & 0.34 & -0.12 & 0.014 & 0.54 \\
Jun & 0,48 & 0.76 & -0.28 & 0.076 & 0.57 \\
\hline \multirow{2}{*}{ Error Value } & & MAD & MSE & MAPE \\
\hline
\end{tabular}

Table 5 shows the results of forecasting with the SARIMA model $(1,1,1)(0,1,1)^{12}$ between January 2018 and June 2018. 


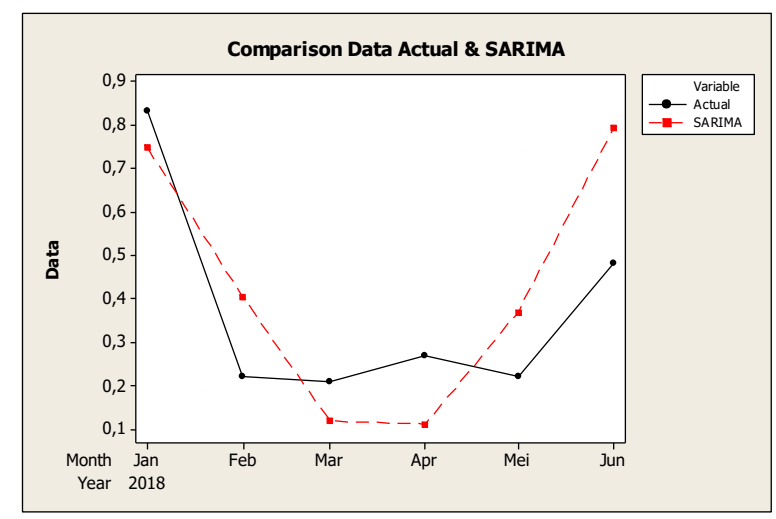

Fig. 9. Comparison Graph Actual Data and SARIMA

The figure is a graphic image comparing the actual value and the SARIMA model $(1,0,1)$ $(1,0,1)^{12}$ with the smallest error value, namely MAD 0.141 , MSE 0.025 and MAPE $0.42 \%$ for forecasting period January 2018 - June 2018.

\section{B. $\quad$ Forecasting Using Single Exponential Smoothing Method}

From the monthly increment data for the January 2011 - December 2017 period, a suitable model for the SES method will be predicted by looking at the forecast results compared to the actual value.

1) Determination Single Exponential Smoothing Model:

The forecasting steps with the SES method are analyzing the data, then the data is predicted by determining the suitable alpha value to be used as the forecasting model. Then comparing the smallest error value, determining the right method is done by trial and error, the parameter value is changed to get the smallest error.

Table 6. Determination Alpha Value

\begin{tabular}{llll}
\hline $\begin{array}{l}\text { Alpha } \\
(\boldsymbol{a})\end{array}$ & MAD & MSE & MAPE \\
\hline $\mathbf{0 , 1}$ & 0,161 & 0,059 & $0.32 \%$ \\
$\mathbf{0 , 2}$ & 0,204 & 0,079 & $0.45 \%$ \\
$\mathbf{0 , 3}$ & 0,206 & 0,073 & $0.48 \%$ \\
$\mathbf{0 , 4}$ & 0,217 & 0,073 & $0.55 \%$ \\
$\mathbf{0 , 5}$ & 0,167 & 0,063 & $0.35 \%$ \\
$\mathbf{0 , 6}$ & 0,224 & 0,071 & $0.63 \%$ \\
$\mathbf{0 , 7}$ & 0,230 & 0,070 & $0.69 \%$ \\
$\mathbf{0 , 8}$ & 0,237 & 0,071 & $0.75 \%$ \\
$\mathbf{0 , 9}$ & 0,244 & 0,072 & $0.80 \%$ \\
\hline
\end{tabular}

In Table VI, we can see the Single Exponential Smoothing model with the smallest MAD, MSE and MAPE error values found in the alpha model 0.1 with MAD values 0.161 , MSE 0.059 and MAPE $0.32 \%$.

2) Forecasting Result Single Exponential Smoothing Method: 
The following are the forecasting results produced by the Single Exponential Smoothing method for inflation movements in $2011-2017$ in the City of Bandung.

Table 7. Result Forecasting SES Method

\begin{tabular}{llllll}
\hline $\begin{array}{l}\text { Period } \\
\mathbf{2 0 1 8}\end{array}$ & $\begin{array}{l}\text { Actual } \\
\text { Value } \\
\text { (a) }\end{array}$ & $\begin{array}{l}\text { Forecasting } \\
\text { Result } \\
(\mathrm{t})\end{array}$ & $\begin{array}{l}\text { Error } \\
\text { Absolut } \\
\left|\mathrm{A}_{\mathrm{t}}-\mathrm{F}_{\mathrm{t}}\right|\end{array}$ & $\begin{array}{l}\text { Square } \\
\text { Of Error } \\
\left|(\mathrm{At}-\mathrm{Ft})^{2}\right|\end{array}$ & $\begin{array}{l}\text { Absolute } \\
\text { Values } \\
\text { Of Errors } \\
|(\mathrm{At}-\mathrm{Ft}) / \mathrm{At}|\end{array}$ \\
\hline Jan & 0,83 & 0,32 & 0.51 & 0.2607 & 0.62 \\
$\mathrm{Feb}$ & 0,22 & 0,29 & 0.07 & 0.0046 & 0.31 \\
Mar & 0,21 & 0,26 & 0.05 & 0.0024 & 0.23 \\
Apr & 0,27 & 0,23 & 0.04 & 0.0014 & 0.14 \\
Mei & 0,22 & 0,21 & 0.01 & 0.0001 & 0.05 \\
Jun & 0,48 & 0,19 & 0.29 & 0.0849 & 0.61 \\
\hline \multirow{2}{*}{ Error Value } & & MAD & MSE 0,059 & MAPE $0,32 \%$ \\
\hline
\end{tabular}

Table 7 shows the results of forecasting with the SES model with an alpha value of 0.1 from January 2018 through June 2018 with MAD values 0.161 , MSE 0.059 , and MAPE $0.32 \%$.

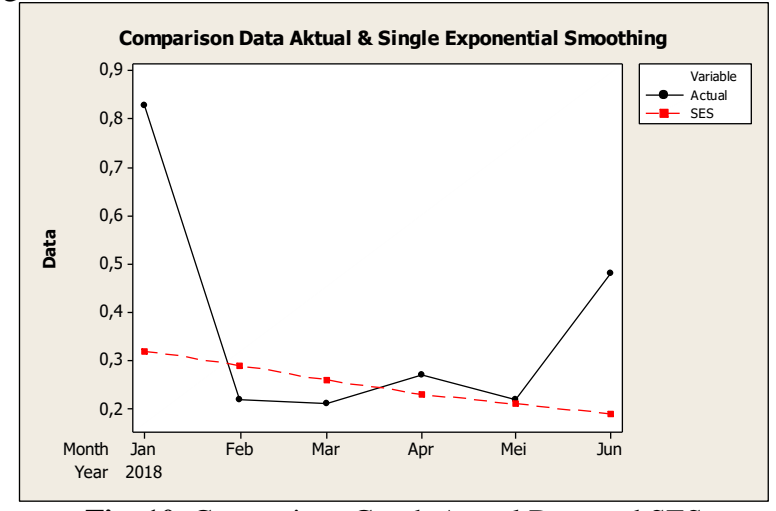

Fig. 10. Comparison Graph Actual Data and SES

Figure 10 is a graphical image comparing the actual value and SES model with an alpha value of 0.1 for the period January 2018 - June 2018 with the smallest error value, namely MAD 0.161 , MSE 0.059 and MAPE $0.32 \%$.

\section{Forecasting Using Hybrid SARIMA-SES Method}

This stage is the stage to model the value of Single Exponential Smoothing from the SARIMA model. Therefore, this stage is referred to as the merging stage; the forecast results from the SARIMA method are then used as input data for the Single Exponential Smoothing model. Mathematically, the overall forecast results obtained are as follows.

\section{1) Forecasting Result SARIMA Method:}

From the results of the prediction of the previous SARIMA method, the best SARIMA model for inflation data is obtained from the SARIMA $(1,0,1)$ model $(1,0,1) 12$ because it has the smallest error value of 0,141 for MAD, 0,025 for MSE and 0,42\% for MAPE 
Table 8. Forecasting Value SARIMA Method

\begin{tabular}{lllllc}
\hline $\begin{array}{l}\text { Period } \\
\mathbf{2 0 1 8}\end{array}$ & $\begin{array}{l}\text { Actual } \\
\text { Value } \\
\text { (a) }\end{array}$ & $\begin{array}{l}\text { Forecasting } \\
\text { Result } \\
\text { (t) }\end{array}$ & $\begin{array}{l}\text { Error } \\
\text { Absolut } \\
\left|\mathrm{A}_{\mathrm{t}}-\mathrm{F}_{\mathrm{t}}\right|\end{array}$ & $\begin{array}{l}\text { Square } \\
\text { Of } \text { Error } \\
\left|(\mathrm{At}-\mathrm{Ft})^{2}\right|\end{array}$ & $\begin{array}{l}\text { Absolute } \\
\text { Values } \\
\text { Of Errors } \\
|(\mathrm{At}-\mathrm{Ft}) / \mathrm{At}|\end{array}$ \\
\hline Jan & 0,83 & 0.68 & 0.15 & 0.021 & 0.18 \\
Feb & 0,22 & 0.30 & -0.08 & 0.006 & 0.35 \\
Mar & 0,21 & 0.17 & 0.04 & 0.002 & 0.21 \\
Apr & 0,27 & 0.09 & 0.18 & 0.033 & 0.67 \\
Mei & 0,22 & 0.34 & -0.12 & 0.014 & 0.54 \\
Jun & 0,48 & 0.76 & -0.28 & 0.076 & 0.57 \\
\hline \multirow{2}{*}{ Error Value } & & MAD & MSE 0,025 & $\begin{array}{c}\text { MAPE } \\
\text { 0,141 }\end{array}$ \\
\hline
\end{tabular}

This shows that this model is proper for forecasting and can be used as input data for the Single Exponential Smoothing model.

2) Forecasting Result Hybrid SARIMA-SES Method:

From the results of forecasting the SARIMA method, the inflation value of forecasting results will be used as input values for forecasting using the Single Exponential Smoothing method.

\begin{tabular}{llll}
\multicolumn{4}{c}{ Table 9. Determination of the Alpha Value } \\
\hline $\begin{array}{c}\text { Alpha } \\
(\boldsymbol{a})\end{array}$ & MAD & MSE & MAPE \\
\hline $\mathbf{0 , 1}$ & 0,259 & 0,086 & $1.05 \%$ \\
$\mathbf{0 , 2}$ & 0,199 & 0,054 & $0.81 \%$ \\
$\mathbf{0 , 3}$ & 0,156 & 0,036 & $0.62 \%$ \\
$\mathbf{0 , 4}$ & 0,118 & 0,025 & $0.46 \%$ \\
$\mathbf{0 , 5}$ & 0,115 & 0,019 & $0.40 \%$ \\
$\mathbf{0 , 6}$ & 0,114 & 0,017 & $0.39 \%$ \\
$\mathbf{0 , 7}$ & 0,116 & 0,018 & $0.40 \%$ \\
$\mathbf{0 , 8}$ & 0,120 & 0,025 & $0,42 \%$ \\
$\mathbf{0 , 9}$ & 0,151 & 0,028 & $0,43 \%$ \\
\hline
\end{tabular}

In Table 9, we can see the Single Exponential Smoothing model with the smallest MAD, MSE and MAPE error values found in the alpha 0.6 model with MAD value 0.114 , MSE 0.017 and MAPE $0.39 \%$.

Table 10. Forecasting Result by Hybrid SARIMA-SES Method

\begin{tabular}{llllll}
\hline $\begin{array}{l}\text { Period } \\
\mathbf{2 0 1 8}\end{array}$ & $\begin{array}{l}\text { Actual } \\
\text { Value (a) }\end{array}$ & $\begin{array}{l}\text { Forecasting } \\
\text { Result } \\
(\mathrm{t})\end{array}$ & $\begin{array}{l}\text { Error } \\
\text { Absolut } \\
\left|\mathrm{A}_{\mathrm{t}}-\mathrm{F}_{\mathrm{t}}\right|\end{array}$ & $\begin{array}{l}\text { Square } \\
\text { Of Error } \\
\left|(\mathrm{At}-\mathrm{Ft})^{2}\right|\end{array}$ & $\begin{array}{l}\text { Absolute } \\
\text { Values } \\
\text { Of Errors } \\
|(\mathrm{At}-\mathrm{Ft}) / \mathrm{At}|\end{array}$ \\
\hline Jan & 0,83 & 0.68 & 0.15 & 0,01 & 0.18 \\
Feb & 0,22 & 0.45 & 0.23 & 0,03 & 1.05 \\
Mar & 0,21 & 0.28 & 0.07 & 0,01 & 0.33 \\
Apr & 0,27 & 0.16 & 0.11 & 0,03 & 0.39
\end{tabular}




\begin{tabular}{llllll}
\hline $\begin{array}{l}\text { Period } \\
\mathbf{2 0 1 8}\end{array}$ & $\begin{array}{l}\text { Actual } \\
\text { Value (a) }\end{array}$ & $\begin{array}{l}\text { Forecasting } \\
\text { Result } \\
(\mathrm{t})\end{array}$ & $\begin{array}{l}\text { Error } \\
\text { Absolut } \\
\left|\mathrm{A}_{\mathrm{t}}-\mathrm{F}_{\mathrm{t}}\right|\end{array}$ & $\begin{array}{l}\text { Square } \\
\text { Of } \text { Error } \\
\left|(\mathrm{At}-\mathrm{Ft})^{2}\right|\end{array}$ & $\begin{array}{l}\text { Absolute } \\
\text { Values } \\
\text { Of Errors } \\
|(\mathrm{At}-\mathrm{Ft}) / \mathrm{At}|\end{array}$ \\
\hline Mei & 0,22 & 0.27 & 0.05 & 0,02 & 0.23 \\
Jun & 0,48 & 0.56 & 0.08 & 0,10 & 0.17 \\
\hline \multirow{2}{*}{ Error Value } & & MAD & MSE 0,017 & $\begin{array}{l}\text { MAPE } \\
0,39 \%\end{array}$ \\
\hline
\end{tabular}

Table 10 shows the forecasting results by combining the SARIMA $(1,0,1)(1,0,1) 12$ method and the Single Exponential Smoothing method with an alpha value of 0.6 for the period January 2018 - June 2018 with an error value of MAD 0.114, MSE 0, 0.17 and MAPE 0.39\%.

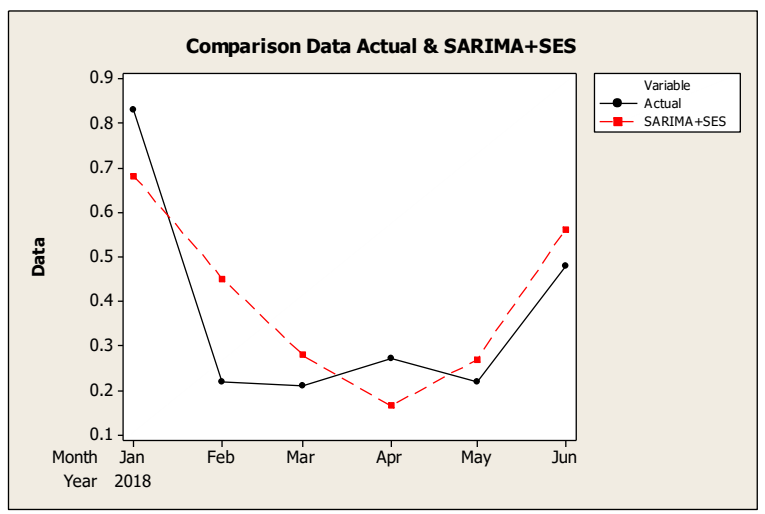

Fig. 11. Comparison Graph Actual Data Hybrid Method

Figure 11 is a graphic image of the comparison of actual values and the merging model of the SARIMA $(1,0,1)$ method $(1,0,1) 12$ and SES with an alpha value of 0,1 for the period January 2018 - June 2018 with the smallest error value that is MAD 0,114, MSE 0.0,17 and MAPE $0.39 \%$. Combining the SARIMA and SES methods results in a smaller error value compared to the use of a single method.

\section{3) Comparison Error Value:}

The following is a comparison of forecasting error values generated by the SARIMA method, the Single Exponential Smoothing and Hybrid SARIMA-SES method on inflation movements in 2011 - 2017 in the Bandung City.

Tabel 11. Comparison Error Value

\begin{tabular}{ccccc}
\hline Period 2018 & Actual & SARIMA & Single Exponential Smoothing & SARIMA+SES \\
\hline Jan & 0,83 & 0.68 & 0,32 & 0.68 \\
Feb & 0,22 & 0.30 & 0,29 & 0.45 \\
Mar & 0,21 & 0.17 & 0,26 & 0.28 \\
Apr & 0,27 & 0.09 & 0,23 & 0.16 \\
Mei & 0,22 & 0.34 & 0,21 & 0.27 \\
Jun & 0,48 & 0.76 & 0,19 & 0.56 \\
\hline & & MAD 0,141 & MAD 0,161 & MAD 0,114 \\
Error Value & & MSE 0,025 & MSE 0,059 & MSE 0,017 \\
& & MAPE $0,42 \%$ & MAPE $0,32 \%$ & MAPE $0,39 \%$ \\
\hline
\end{tabular}


In Table 11, it is shown that the results of the Hybrid SARIMA-SES method are better than using a single method. Judging from the MAD, MSE and MAPE values which are smaller than the MAD, MSE and MAPE values of the other two models, the MAD values are 0.141, MSE 0.017 and $0.39 \%$ for MAPE. The following is a graph of the comparison of actual values, the SARIMA method, the Single Exponential Smoothing method, and the Hybrid SARIMA-SES method.

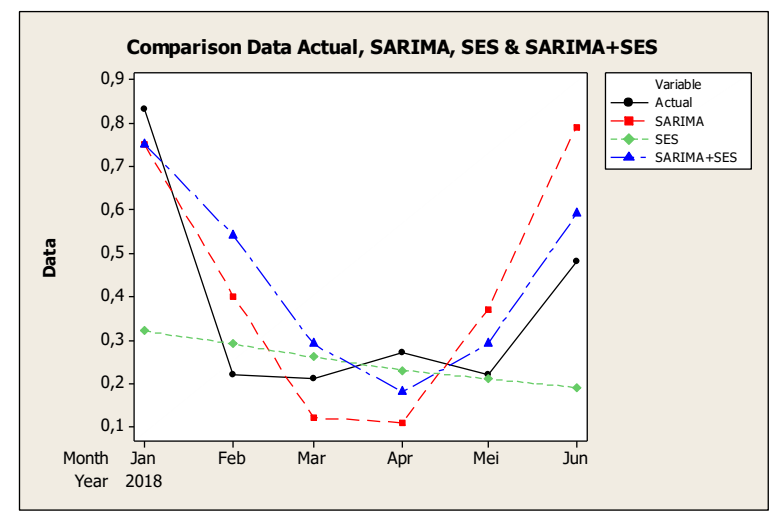

Fig. 12. Comparison Graph Actual Data, SARIMA, Single Exponential Smoothing, and Hybrid SARIMA \& SES

Figure 12 is a graphical picture of the comparison of the actual inflation value, the inflation value of SARIMA forecasting results, the inflation value forecasting results of Single Exponential Smoothing and the inflation value of the Hybrid SARIMA-SES method. It can be seen if the error value generated by the Hybrid SARIMA-SES method has a smaller error value than using a single method.

\section{Decent Living Costs}

Decent living needs are the standard of living needs of a single worker/laborer to be able to live physically and non-physically in one month. There are 60 items calculated in HKL which are grouped in 7 components, among them: food and drinks (11 items), clothing (13 items), housing (26 items), education ( 2 items), health ( 5 items), transportation ( 1 item), recreation and savings ( 2 items). However, in this study, the author will focus more on food and beverage components with 11 items. Food data is obtained from the average commodity consumer prices in the city of Bandung from the Food Price Information Portal.

Table 12. Standard KHL for December 2017 Based on Food and Drink Components

\begin{tabular}{clccc}
\hline No. & \multicolumn{1}{c}{ Component } & Quality & Needs & Price \\
\hline 1 & Medium Rice & Medium & $10 \mathrm{~kg}$ & Rp126,240 \\
& $\begin{array}{l}\text { Protein Source: } \\
\text { a. Meat }\end{array}$ & Medium & $0.75 \mathrm{~kg}$ & $\mathrm{Rp} 84,083$ \\
2 & b. Fresh fish & Good & $1.2 \mathrm{~kg}$ & $\mathrm{Rp} 85,082$ \\
& c. Chicken eggs & Good & $1 \mathrm{~kg}$ & $\mathrm{Rp} 20,623$ \\
& Nuts: tempeh / tofu & Good & $4.5 \mathrm{~kg}$ & $\mathrm{Rp} 51,156$ \\
3 & Milk powder & Medium & $0.9 \mathrm{~kg}$ & $\mathrm{Rp} 32,940$ \\
5 & Sugar & Medium & $3 \mathrm{~kg}$ & $\mathrm{Rp} 40,104$ \\
6 & Cooking oil & Curah & $2 \mathrm{~kg}$ & $\mathrm{Rp} 23,168$ \\
7 & Vegetables & Good & $7.2 \mathrm{~kg}$ & $\mathrm{Rp} 72,000$
\end{tabular}




\begin{tabular}{clccc}
\hline No. & \multicolumn{1}{c}{ Component } & Quality & Needs & Price \\
\hline 8 & $\begin{array}{l}\text { Fruits (equivalent to } \\
\text { banana) }\end{array}$ & Good & $7.5 \mathrm{~kg}$ & $\mathrm{Rp70,500}$ \\
9 & $\begin{array}{l}\text { Other carbohydrates } \\
\text { (equivalent to flour) }\end{array}$ & Medium & $3 \mathrm{~kg}$ & $\mathrm{Rp} 45,000$ \\
10 & $\begin{array}{l}\text { Tea or Coffee } \\
\text { Spices }\end{array}$ & $\begin{array}{c}\text { Dip/Sachet } \\
\text { Value 1-10 }\end{array}$ & $\begin{array}{c}2 \mathrm{Box} \\
1 \mathrm{~kg}\end{array}$ & $\begin{array}{c}\mathrm{Rp} 11,000 \\
\mathrm{Rp} 35,700\end{array}$ \\
\hline Total & & & & $\mathrm{Rp697,596}$ \\
\hline
\end{tabular}

Table 12 shows food data for December 2017 in Bandung City with 11 items stipulated by Minister of Manpower Decree No. 13 of 2012.

1) KHL Based on Inflation by SARIMA:

The following is the KHL value generated by the calculation results with the inflation value predicted using the SARIMA method. The initial value of KHL is taken from the KHL value in December 2017.

Table 13. KHL Based On Inflation SARIMA Value

$$
\text { Decent Living Costs }
$$

Period (Minimum/Month/Capita)

\begin{tabular}{llll}
\cline { 2 - 4 } 2018 & Actual & SARIMA & \\
\cline { 3 - 4 } & KHL & Inflation & KHL \\
\hline Jan & Rp 686,665 & 0.68 & Rp 687,572 \\
Feb & Rp 690,973 & 0.30 & Rp 690,249 \\
Mar & Rp 691,421 & 0.17 & Rp 691,157 \\
Apr & Rp 687,742 & 0.09 & Rp 691,696 \\
Mei & Rp 691,121 & 0.34 & Rp 689,957 \\
Jun & Rp 689,053 & 0.76 & Rp 687,074 \\
\hline
\end{tabular}

Table 13 is the result of forecasting the KHL value based on the results of calculations with the inflation value generated by SARIMA forecasting.

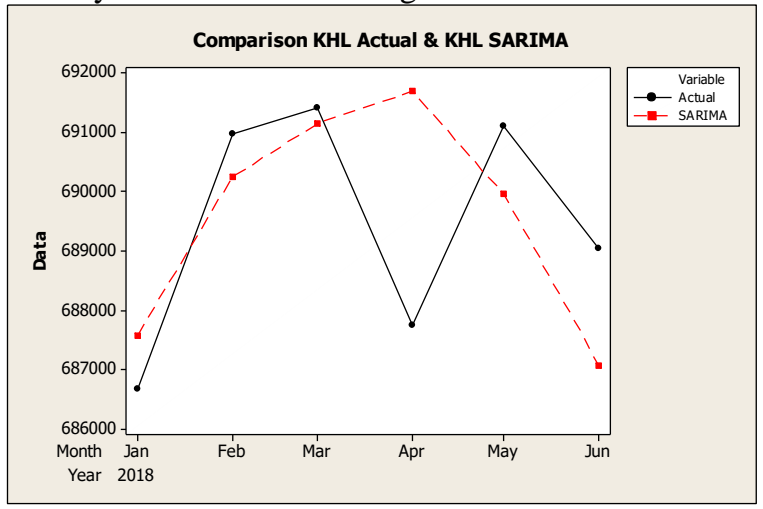

Fig. 13. Comparison Graph Actual KHL and KHL SARIMA

Figure 13 shows a graph of the comparison of the actual KHL and KHL values based on the accumulated inflation value generated by SARIMA forecasting.

2) KHL Based on Inflation by SES: 
The following is the KHL value generated by the calculation results with the inflation value predicted using the Single Exponential Smoothing method.

Table 14. KHL Based on Inflation SES Value

\begin{tabular}{llll}
\multicolumn{4}{c}{ Table 14. KHL Based on Inflation SES Value } \\
\hline \multirow{3}{*}{$\begin{array}{l}\text { Periode } \\
2018\end{array}$} & $\begin{array}{l}\text { Decent Living Costs } \\
\text { (Minimum/Month/Capita) }\end{array}$ \\
\cline { 2 - 4 } & Actual KHL & SES & \\
\cline { 2 - 4 } & Inflation & KHL \\
\hline Jan & Rp 66,665 & 0,32 & Rp 690,095 \\
Feb & $\operatorname{Rp~690,973~}$ & 0,29 & Rp 690,316 \\
Mar & Rp 691,421 & 0,26 & Rp 690,515 \\
Apr & Rp 687,742 & 0,23 & Rp 690,694 \\
Mei & $\operatorname{Rp~691,121~}$ & 0,21 & Rp 690,855 \\
Jun & $\operatorname{Rp~689,053~}$ & 0,19 & Rp 691,000 \\
\hline
\end{tabular}

Table 14 is the result of forecasting the KHL value based on the results of calculations with the inflation value generated by the Single Exponential Smoothing forecasting.

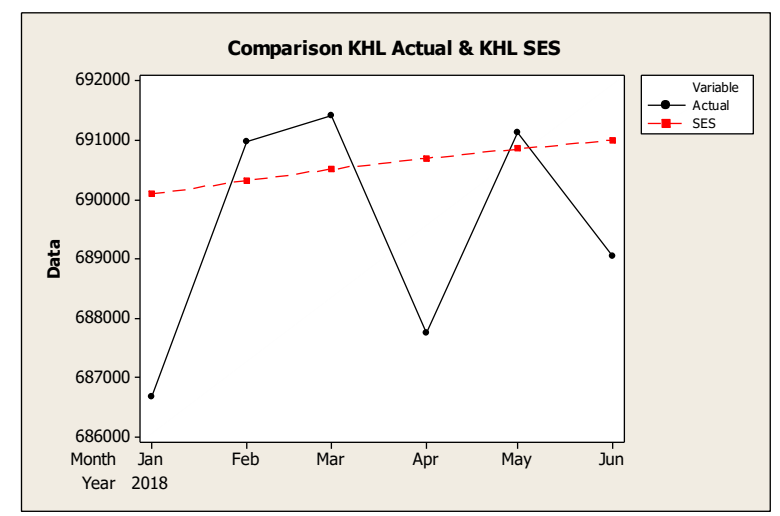

Fig. 14. Comparison Graph Actual KHL and KHL SES

Figure 14 shows a graph of the comparison of the actual KHL and KHL values based on the accumulated inflation value generated by SARIMA forecasting.

3) KHL Based on Inflation by Hybrid SARIMA-SES:

The following is the KHL value generated by the calculation results with the inflation value predicted using the Hybrid SARIMA-SES method. 
Table 15. KHL Based on Inflation Hybrid Sarima-Ses Value Decent Living Costs

\begin{tabular}{|c|c|c|c|}
\hline \multirow{3}{*}{$\begin{array}{l}\text { Period of } \\
2018\end{array}$} & \multicolumn{3}{|c|}{ (Minimum/Month/Capita) } \\
\hline & \multirow{2}{*}{ Actual KHL } & \multicolumn{2}{|c|}{ Hybrid SARIMA-SES } \\
\hline & & Inflation & KHL \\
\hline January & $\operatorname{Rp} 686,665$ & 0.68 & $\operatorname{Rp} 687,583$ \\
\hline February & Rp 690,973 & 0.45 & $\operatorname{Rp} 689,182$ \\
\hline March & Rp 691,421 & 0.28 & $\operatorname{Rp} 690,367$ \\
\hline April & Rp 687,742 & 0.16 & $\operatorname{Rp} 691,164$ \\
\hline May & $\operatorname{Rp} 691,121$ & 0.27 & $\operatorname{Rp} 690,440$ \\
\hline June & Rp 689,053 & 0.56 & $\operatorname{Rp} 688,421$ \\
\hline
\end{tabular}

Table 15 is the result of forecasting the KHL value based on the results of calculations with the inflation value generated by the Hybrid SARIMA-SES forecast.

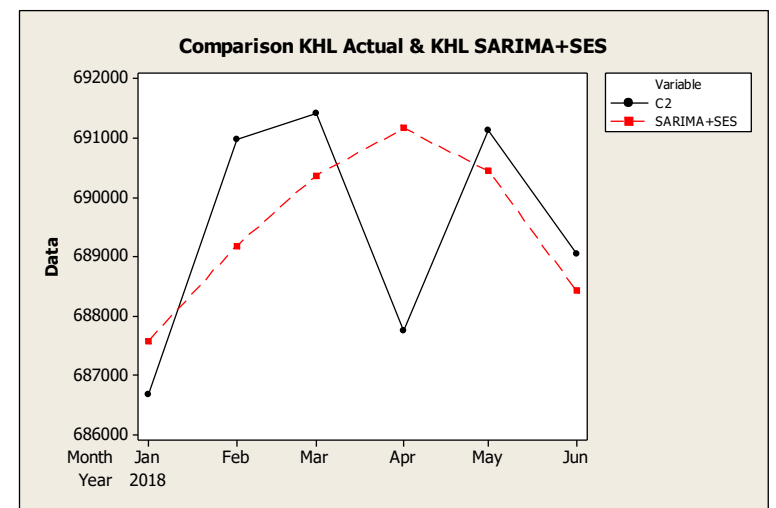

Fig. 15. Comparison Graph Actual KHL and KHL Hybrid SARIMA- SES

Figure 15 shows a graph of the comparison of actual KHL and KHL values based on the accumulated inflation value generated by forecasting the Hybrid SARIMA-SES method. The following is a graph of the comparison of KHL values based on the results of calculations with the outcome of the inflation value.

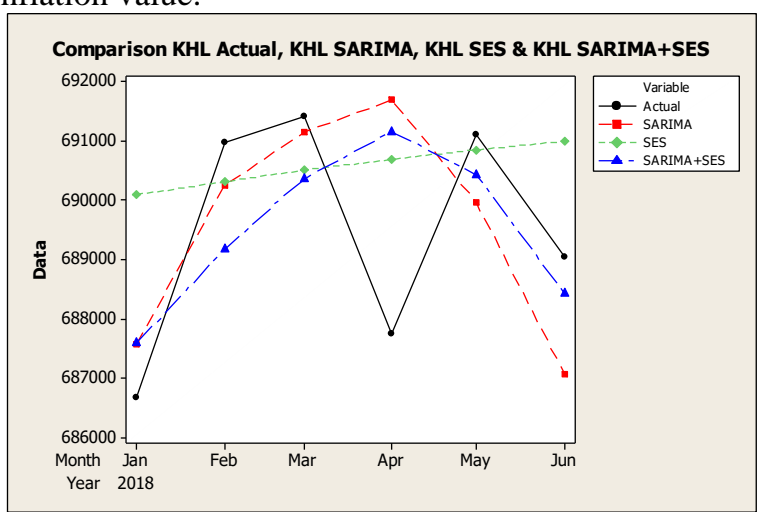

Fig. 16. Comparison Graph KHL Value 
Figure 16 is a graphical picture comparing the value of actual decent living needs, the value of decent living needs calculating by the SARIMA forecasting inflation value, the inflation value forecasted by Single Exponential Smoothing and the inflation value of the Hybrid SARIMASES method.

\section{Conclusion}

The use of the Hybrid SARIMA-SES method for forecasting the inflation value of the city of Bandung resulted in a more accurate forecasting value than using a single method, with MAD error value of 0.114 , MSE 0.017 and MAPE $0.39 \%$. So that the results of the implementation of Bandung City inflation forecasting for the next period can be used as a reference for calculating the estimated value of decent living needs. The results of the calculation of the value of decent living based on calculations with the value of inflation have a perfect result because it approaches the actual value of the necessities of decent living for the food and beverage category. The results of calculating the index of living needs can also be used as a reference to estimate whether or not a single worker can fulfill their daily needs for one month, in this case concerning the cost of food and drinks for one month in the city of Bandung.

\section{Acknowledgements}

This work supported in part by the research grant for Hibah Tesis Magister with No. 2898/L4/PP/2019 and received from Kementerian Riset, Teknologi dan Pendidikan Tinggi (RISTEKDIKTI), Indonesia

\section{References}

[1] Hidayat Muharam, S. H.: Panduan memahami hukum ketenagakerjaan serta pelaksanaannya di Indonesia. Citra Aditya Bakti (2006)

[2] Kerja, P. M. T., \& Nomor, T.: Tahun 2012 Tentang Komponen dan Pelaksanaan Tahapan Pencapaian Kebutuhan Hidup Layak (2013)

[3] Khakim, A.: Aspek hukum pengupahan: berdasarkan UU nomor 13 tahun 2003. Citra Aditya Bakti (2006)

[4] Peraturan Menteri Tenaga Kerja dan Transmigrasi RI No. 13 Tahun 2012 tentang Komponen dan Pelaksanaan Tahapan Pencapaian Kebutuhan Hidup layak (2013)

[5] Suseno, S. A.: Inflasi. Jakarta: Pusat Pendidikan dan Studi Kebanksentralan (PPSK) BI (2009)

[6] Swandayani, D. M., \& Kusumaningtias, R.: Pengaruh Inflasi, Suku Bunga, Nilai Tukar Valas dan Jumlah Uang Beredar terhadap Profitabilitas pada Perbankan Syariah di Indonesia Periode 2005-2009. AKRUAL: Jurnal Akuntansi, 3(2), 147-166 (2012)

[7] A. Sofyan.: Teknik dan metode peramalan, Jakarta Penerbit Fak.Ekonomi Universitas Indonesia (1984)

[8] W. W. S. Wei.: Time Series Analysis Univariate and Multivariate Methods SECOND EDITION (2006)

[9] Pongdatu, G. A. N., \& Putra, Y. H.: Seasonal Time Series Forecasting using SARIMA and Holt Winter's Exponential Smoothing. In IOP Conference Series: Materials Science and Engineering (Vol. 407, No. 1, p. 012153). IOP Publishing (2018) 
[10] B. L Bowerman and R. T O Connell.: Forecasting and time series : an applied approach / Bruce L. Bowerman, Richard T. O`Connell (2018)

[11] Biri, R., Langi, Y. A., \& Paendong, M. S.: Penggunaan Metode Smoothing Eksponensial dalam Meramal Pergerakan Inflasi Kota Palu. Jurnal Ilmiah Sains, 13(1), 68-73 (2013)

[12] Zhang G.: Time series forecasting using a hybrid ARIMA and neural network model. J.Neurocomputing50:159-175 (2003)

[13] S. G. Makridakis, S. C. Wheelwright, and R. J. Hyndman, Forecasting: Methods and Applications, J. Forecast., p. 1 (1998)

[14] Tayman, J., \& Swanson, D. A.: On the validity of MAPE as a measure of population forecast accuracy. Population Research and Policy Review, 18(4), 299-322 (1999)

[15] Hyndman, R. J., \& Athanasopoulos, G.: 2nd Edition. Forecasting: principles and practice. Otexts (2018) 